\title{
Käsikirja teollistuneiden maiden aikuiskasvatuksesta
}

Peterson ym. (eds.) 1982. Adult education and training in industrialized countries. New York: Praeger Publishers. $500 \mathrm{~s}$.

Prager kustantamo on julkaissut yhdessä New Yorkin valtionyliopiston vertailevan kasvatustieteen keskuksen kanssa laajan teoksen aikuiskasvatuksesta eräissä teollistuneissa maissa. Vaikka vastaavia eri maiden aikuiskasvatusjärjestelmiä kuvaavia teoksia onkin olemassa jo useita (esim. OECD:n vuonna 1977 julkaisema ',Learning opportunities for adults"'), niin teos antanee eri maiden aikuiskasvatusjärjestelmistä kiinnostuneille runsaasti hyödyllistä ja suhteellisen uutta tietoa. Kirjan selkeä jäsentely, sen lopussa olevat nimi- ja asiahakemistot sekä suppeat bibliografiat eri maiden keskeisimmistä suunnittelu- ja tutkimusdokumenteista tekevät siitä hyödyllisen käsikirjan, josta on helppo löytää kulloinkin lukijaa kiinnostavat asiakokonaisuudet. Kirjan hinta (450 mk) taannee kuitenkin sen, ettei se tule kuulumaan kovinkaan monen aikuiskasvattajan käsikirjastoon.

Kirjassa esitellään seuraavien maiden aikuiskasvatusjärjestelmiä: Australia, Kanada, Tanska, Saksan liittotasavalta, Ranska, Neuvostoliitto, Ruotsi, Yhdistynyt kuningaskunta (U.K) sekä Yhdysvallat. Kirjan ensimmäisessä luvussa luodaan lyhyt yleiskatsaus eri maiden aikuiskasvatuksen historiaan ja nykyiseen järjestelmään. Toisessa luvussa käsitellään eräiden valikoitujen väestöryhmien osallistumismahdollisuuksia näissä maissa. Tarkasteltavat väestöryhmät ovat: työntekijät (laajasti ymmärrettynä), vanhukset, työelämään palaavat naiset, lasten vanhemmat ja lyhyen koulutuksen saaneet. Sitä miksi juuri nämä väestöryhmät on otettu mukaan ei tarkemmin perustella, mutta ilmeisesti ryhmät on koettu jollakin tavalla aikuiskasvatuksen kannalta tärkeinä väestöryhminä. Jaottelua voidaan pitää hyvin perusteltuna, sillä onhan näillä ryhmillä kullakin omat erityiset opiskelutavoitteensa ja ongelmansa. Ainakin jaottelua voi pitää onnistuneempana kuin tavanomaista organisaatiopohjaista luokittelua. Mainittakoon että ensimmäisellä kohderyhmällä '’työntekijöillä', (workers) tarkoitetaan kaikkia työelämässä toimivia henkilöryhmiä sekä myös työllisyyskoulutukseen osallistuvia. Kirjassa käytetäänkin myös käsitettä työelämään liittyvä koulutus (workrelated training), joka kuvaa tarkemmin tässä osassa käsiteltäviä asioita. Tällainen otsake ei vaan olisi soveltunut kirjassa käytettyyn kohderyhmäluokitteluun. Kohderyhmittäinen tapahtuva tarkastelu on ehkä kirjan kiinnostavin ja antoisin luku. Siinä saa hyvän kuvan niistä keinoista, joita eri maissa on käytetty näiden erityisryhmien mukaansaamiseksi opiskeluun. Siinä käy myös selvästi ilmi, että eri maissa näiden ryhmien erityisongelmiin on kiinnitetty juomiota varsin eri tavoin. Tämä ilmenee erityisesti työhön palaavien naisten ja vanhusten kohdalla. Kirjan kolmannessa luvussa luodaan vielä lyhyt katsaus tarkasteltavissa maissa harjoitettuun aikuiskasvatuspolitiikkaan, koulutusohjelmiin ja järjestelmän rakenteeseen. Ilmeisesti julkaisumaasta johtuen kirjan neljäs luku on omistettu Yhdysvaltojen hallituksen harjoittaman aikuiskasvatuspolitiikan lähempään esittelyyn. Tässä luvussa vertaillaan myös jonkin verran Yhdysvaltojen ja muiden maiden aikuiskasvatusta keskenään.

Eräs aina kiinnostava seikka on osallistumislukujen vertailu eri maiden kesken. Kirjan mukaan vuosittaiset osallistumisprosentit ovat seuraavanlaiset: Australia 13, Kana- da 23, Tanska 17, Saksan liittotasavalta 11, Ranska 7, Neuvostoliitto 31, Ruotsi 29, Yhdistynyt kuningaskunta 15 ja Yhdysvallat 27. Vaikka tilastoinnissa on varmasti suuria eroja, kuvannevat nämä luvut suurin piirtein tilannetta eri maissa. Osallistumisluvut on kerätty vuosilta 1977 tai 1978. Meillä Suomessa ei ole tehty vastaavia laskelmia juuri noilta vuosilta, mutta Tilastokeskuksen selvityksen mukaan meillä osallistui vuonna 1980 noin $26 \%$ aikuisista erilaiseen opintotoimintaan. Vaikka otamme huomioon pienen eron tutkimusajankohdissa (ilmeistä on että osallistumisluku oli meillä vuonna 1978 pari prosenttiyksikköä alhaisempi), niin voimme todeta, että meillä ei ole mitään hävettävää aikuiskasvatuspalvelustemme kehitystasossa.

Kirjan puutteena voidaan pitää sitä, että se on yleisluonteeltaan kuvaileva. Siinä ei ole yritettykään systemaattisesti vertailla ja analysoida tilannetta eri maiden kesken. Se jätetään lukijan tehtäväksi. Olisi odottanut, että kirjan toimittajat olisivat laatineet edes jonkinlaisen yhteenvedon aineistosta ja arvion aikuiskasvatuksen kehitystilasta eri maissa. Valitettavana voi pitää myös sitä, että Neuvostoliiton osalta tiedot on koottu pelkästään amerikkalaisten toimesta, kun sen sijaan kaikkien muiden maiden kohdalla kirjoittajana on ollut joku k.o. maan aikuiskasvatuksen asiantuntija. Niinpä Neuvostoliittoa koskevat jaksot ovatkin muita suppeampia ja yleisempiä. Näistä puutteistaan huolimatta kirja sisältää runsaasti tietoa eri maiden aikuiskasvatuksen historiasta, nykyisistä järjestelmistä ja harjoitetusta aikuiskasvatuspolitiikasta. Tästä syystä sitä voi pitää hyödyllisenä käsikirjana alan suunnittelijoille ja tutkijoille.

Jukka Tuomisto 